Economica XI. Új évf., 1-2. sz. (2020)

ISSN 2560-2322

\title{
A TURIZMUS, MINT A VIDÉKI TÉRSÉGEK KITÖRÉSI LEHETŐSÉGE
}

\section{TOURISM AS AN OUTBREAK POSSIBILITY FOR RURAL REGIONS}

Kovács Edit Veronika ${ }^{1}$

1 Debreceni Egyetem Gazdaságtudományi Kar, Vidékfejlesztés, Regionális Gazdaságtan és Turizmusmenedzsment Intézet

\author{
Kulcsszavak: \\ turizmus \\ vidék \\ fejlődés \\ egészség \\ munkavállalás
}

Keywords:

tourism

countryside

development

health

employment

\section{Összefoglalás}

A cikk célja a turizmus, mint a vidéki térségek fejlődését támogató jelenség bemutatása. A turizmus gazdaságra gyakorolt jótékony hatásai a beruházások és a munkaeröpiac területén is jelentkeznek. A turizmus képes pozitív hatást gyakorolni a lakosság egészségi állapotára is, nem kis részben a sportnak köszönhetöen. A vidéki térségek turisztikai fejlesztései eredményeként a mezőgazdasági munkavállalással felhagyó állampolgárok a szolgáltató szektorban helyezkedhetnek el.

\section{Abstract}

The aim of the article is to present the tourism as a potential developing phenomenon of the rural areas. The positive impacts of the tourism on the economy and appear in connection with the labour market and the investments. Tourism can have a postive effect on the health condtions of the citizens, mostly because of the increase of the sporting activity level. The employees formerly employed by the agricultural sector can easier move to the service sector because of the development of the rural areas.

\section{Bevezetés}

A 21. század egyik kiemelt jelentőségű témája a vidék fejlesztésének, a vidék fejlődésének különböző lehetőségei. Ezek közül kell kiemelni a turisztikai fejlesztések pozitív hatásait a gazdaság fejlődésére. Kiss (2018) cikkében kiemeli, hogy a vidéki turisztikai fejlesztések kiemelt célja valamilyen információ összekötése a potenciális célközönség fejében egy adott földrajzi területtel, továbbá a turisztikai szezon hosszának elnyújtása. Mindez a gyakorlatban tehát azt jelenti, hogy a vidéki turizmus során annak szervezői az adott régióról igyekszenek többlettudást átadni a vendégeknek, ráadásul lehetőleg minél hosszabb időszak során. A fejlesztésekkel több cél is elérhető, ezek egy része kulturális vagy társadalmi eredmények realizálásával kecsegtet, azonban mindenképpen alá kell húzni a vidéki turisztikai fejlesztések potenciális pozitív gazdasági hatásait is.

A vidékfejlesztés ugyanakkor, miként arra Vargáné Csobán és Serra (2016) is rámutat, többet jelent a helyi gazdaság fejlesztésénél. A sikeres vidékfejlesztési tevékenység eredményeként ugyanis javul a helyben élők életminősége, a fejlesztésbe bevont terület élhetősége is, ami alkalmas lehet a vidéket érintő legsúlyosabb problémák, így kiemelten a népesség elvándorlása és az elöregedés problémáinak részbeni orvoslására is. Fontos eleme továbbá a vidékfejlesztésnek a fenntarthatósági célok szem előtt tartása is, ennek köszönhetően 
pedig a vidéki területek könnyebben meg tudják őrizni arculatuknak azon jellegzetességeit, amelyekhez hagyományosan pozitív társadalmi értékítéletek tartoznak. Ilyen elem lehet például az egészséges életmód folytatásával kapcsolatos lehetőségek erősödése is, ami egyértelműen pozitív eleme a vidéki területek fejlődésének. Jelen cikk célja a turizmus lehetőségeinek feltárása a vidékfejlesztés területén.

\section{Alkalmazott módszerek}

Jelen cikk célja a vizsgált témakör szakirodalmának feltárása és szintetizálása, ennek eredményeként pedig olyan újszerű megállapítások megfogalmazása, amely nemcsak a kutatói közösség, hanem a gyakorló felhasználói szféra számára is hasznosítható információkat hordoz és terjeszt. Kothari (2004) nagy kutatásmódszertani szakkönyvében részletesen foglalkozott a szekunder kutatási módszerek körébe sorolt szakirodalmi feltárás és szintézis jelentőségével, előnyeivel, hátrányaival és gyakorlati megvalósításával. Meglátása szerint voltaképpen minden kutatást az elérhető források feltárásával kell kezdeni, hiszen így nemcsak az lesz elkerülhető, hogy már korábban megtett tudományos megállapítások újbóli igazolására törekedjenek a kutatók, hanem az elemzők rendelkezésére álló szúkös erőforrások, így mindenek előtt idő és munkaidő, továbbá a pénzügyi források felhasználása is sokkal racionálisabban, hatékonyabban történhet. Amennyiben a kutatók nem ellenőrzik kellő alapossággal a vizsgált témakör már elérhető szakirodalmát, könnyen előfordulhat, hogy mások által már igazolt felvetések bizonyítására pazarolják el korlátos forrásaikat. Emellett a szakirodalmi feltárás segíthet a kutatóknak hazai vagy nemzetközi téren is kontextusba helyezni az adott vizsgálatokat. Így aztán igaz ugyan, hogy a szekunder adatfeltárást és szintézist a legtöbben gyors és olcsó kutatási módszernek tartják, azonban a szekunder források feltárása esetén a kutatók mindig csak limitált információmennyiséghez juthatnak, hiszen kizárólag azon az adott mintán elért, az idézett mű szerzője által kidolgozott kutatási célkoordinátában elért, publikált tudományos közlések tartalmát lehet idézni és szintetizálni. Ez a kitettség akár komolyabb problémát is okozhat, hiszen a készakarva közölt fals adatok jóhiszemú és etikus felhasználása a feldolgozó közlemények - és szerzőik - morális szavahihetősége szempontjából is komoly aggályokat vethetnek fel.

Harris (1998) kutatásmódszertani múvében ugyanakkor arra is rámutat, hogy elméleti megalapozás nélkül a tervezett kutatások semmiképpen sem megvalósíthatóak. Mindez a gyakorlatban azt jelenti, hogy a kutatási tervek megvalósítása során kiemelt jelentőséggel bír a szakirodalmi szintézis nívós kivitelezése, amelynek eredményei tudományos publikációként önmagukban véve is megállják helyüket.

\section{A vidék és a turizmus kapcsolata}

Az elmúlt évek során egyre több figyelem hárul a turizmus, ezen belül is elsősorban a tömeges turizmus negatív hatásaira. Garau-Vadell és szerzőtársai (2018) kiemelik, hogy gazdasági krízisek, válságok hatására a helyi lakosok hozzáállása a turizmushoz - és tekintettel arra, hogy vizsgálatukat egyebek mellett Tenerifén is végezték, kijelenthető, hogy a tömegturizmushoz is - jelentősen pozitívabbá válnak. A negatív hatások háttérbe szorulnak, hiszen a helyi lakosok is a vendéglátás pozitív gazdasági hatásaiban kezdenek reménykedni. Indonéz példán szemléltetve az is látható, hogy a turizmus negatív hatásai ellenére is jelentős fejlesztési potenciálként jelenhet meg. A turizmus tömegessé válása által generált gazdasági hatások eredményei a lakosság és a nemzetgazdaság helyzetének javulásában is megjelenhet (Lee - Syah, 2018), azonban hosszabb távon kontraproduktívvá válhat. Török példák ugyanakkor arra is rámutattak, hogy a tömeges turizmus fejlesztése lehet ugyan nemzetgazdasági stratégiai cél, azonban ebből a helyi lakosok kevéssé profitálnak. Míg a turisták jellemzően több erőforrást használnak fel, mint a helyiek és ráadásul hulladéktermelésük szintje is magasabb időarányosan a helyiekénél, a helyben élő lakosság gazdasági előnyei igen korlátozottak. A tömegturizmus ugyan képes álláshelyeket teremteni, ezek többsége azonban időszaki munkavállalást tesz lehető́vé, ráadásul alacsonyan képzett és éppen ezért alacsonyan is bérezett munkavállalók számára, azonban ezzel egyidejűleg jelentősen növelheti a megélhetés költségeit a helyiek számára, például a növekvő lakhatási és 
étkezési költségek miatt, ráadásul szinte teljesen el is lehetetlenítheti a helyiek hozzáférését a turisztikai attrakciókhoz (Egresi, 2016).

A tömegessé váló turizmus hatásait azonban maguk a turisták is érzékelik, akik egyre nagyobb arányban vágynak arra, hogy olyan helyekre látogathassanak el, amelyek valamilyen egyedi élményt kínálnak a látogatóknak, ugyanakkor még nem túlterheltek a tömegturizmus hatásaitól. Ilyen élmény lehet a különböző épített és kulturális értékek mellett egy-egy tájegység természeti öröksége is, amelynek felfedezése unikális turisztikai emlékeket jelenthet a fogyasztók számára. Ennek eredményeként a vidéki Magyarország egyre több települése reménykedik abban, hogy a gazdasági fellendülés motorja a turizmus lesz majd (Dancsokné Fóris et al., 2019). Ezzel a folyamattal párhuzamosan ugyanakkor az is tapasztalható Magyarországon, hogy a vidéki térségek egy része egyre nagyobb leszakadást mutat, a rendszerváltás óta az egyes térségek gazdasági fejlettsége között növekszik a különbség. A vidéki térségek fejlesztése az esetek döntő hányadában valamilyen központi forrás, költségvetési támogatás vagy európai uniós hozzájárulás segítségével valósulhat meg. Mindez elsősorban azért jelent problémát, mert így a települések gyakorta nem saját szükségleteik, hanem a felmerülő pályázati lehetőségeik szerint igényelnek támogatásokat a fejlesztések megvalósításához. A vidéki térségekben jelentős munkaerőpiaci átrendeződés is megfigyelhető volt, a munkavállalók egyre kisebb hányada dolgozik a mezőgazdaságban, a más ágazatokba kényszerülook száma emelkedik (Oláh et al., 2017). A mezőgazdasági szektor munkavállalás szempontjából vett attraktivitásának csökkenése (Dajnoki - Kun, 2016; Fróna - Kőmíves, 2019; Kőmíves et al., 2019) lépéskényszerbe hozza a településeket, amit erősít a mezőgazdaság általános forráshiányos állapota (Popp et al., 2018; Fenyves et al., 2019; Fenyves et al., 2020), a turizmus fejlesztése pedig előnyös lehetőség lehet a települések és térségek gazdasági fejlesztése szempontjából.

A települések fejlődése szempontjából kiemelkedő jelentősége lehet egy-egy elhivatott helyi vezetônek vagy társadalmi szervezetnek. Az ő elhivatottságuk jelentősen növelheti a rendelkezésre álló források mennyiségét, illetve azok felhasználásának hatékonyságát. Kulcselem ugyanakkor, hogy a helyi vezetők és szervezetek jól ismerik az adott település vagy térség múködését, kultúráját, így képesek megtalálni azokat a fejlesztési pontokat, amelyek támogatása a befektetések megtérülését eredményezi (Nemes, 2018). A helyi turisztikai fejlesztések egyik alapja lehet a helyi tradíciókra épülő termékek előállítása és kereskedelme. Amennyiben ezek a termékek jelentősebb kulturális hozzáadott értékkel is bírnak, a jelenség turisztikai vonzereje még erősebb lehet (Szőllősi et al., 2014). A vidéki Ausztria bevételeiben is kiemelt jelentőséggel bír a helyi termékek értékesítése, illetve az ehhez gondolatilag igen erősen kötődő vidéki turizmus jelenléte (Mezei et al., 2018).

\section{A vidék és az egészség turisztikai kapcsolata}

A falusi turizmus helyett alkalmazni javasolt vidékturizmus kifejezés hitelesebben mutatja be a vidéki térségek turizmusára jellemző arculati gazdagságot. A vidéki térségek ugyanis a szinte lakatlan területektől a kisvárosias életkörnyezetekig számos térségi típust magukba olvasztanak, így annak jellemzése messze nem írható le a falu kifejezés alkalmazásával (Gulyás, 2019).

Magyarország fejlődése szempontjából minden olyan lehetőség kiemelt jelentőséggel bír, amely a lakosság egészségi állapotát javítani képes (Hegedüs, 2014). Noha a fizikailag aktív felnőtt lakosság aránya növekvő tendenciát mutat, az országban még mindig nagyon sok a túlsúlyos vagy elhízott ember. Mindennek folyományaként azon lehetőségek, amelyek a lakosság egészségi állapotának javulását eredményezik, széles körű társadalmi támogatottságra tehetnek szert (Bácsné Bába et al., 2020).

A turizmus, ezen belül pedig az egészségturizmus célja a turisták életminőségének javítása, amely ebben az esetben az egészségi állapot javulását eredményezi. Természetesen minden betegség esetében fel lehet állítani olyan turisztikai terveket, amelyek eredményeként javulhat a betegek egészsége és életminősége (Müller et al., 2018), bizonyos tömeges betegségek esetében azonban kiemelten rentábilis lehet nagyobb létszámú turizmust is lehetővé tevő fejlesztések bevezetése. 
A felvázolt folyamatok eredményeként az elmúlt évek, évtizedek folyamán a vidéki térségek által ellátott funkciók jelentősen megváltoztak. Ennek eredményeként, noha a vidéki térségek továbbra is kulcsszerepet játszanak a lakosság élelmiszerellátásában, ezzel egyidejúleg az egészség megőrzésében is egyre nagyobb lett a jelentőségük. A környezeti célkitüzések mellett hangsúlyosan érvényre jut az egészség megőrzése, a betegségek megelőzése - és ezekhez kapcsolódva maga a sport is. A változások célja, hogy megállítsa az országokon belüli migrációs folyamatokat, amelyek eredményeként a vidéki lakosság folyamatosan áramlik a városokba, ennek hatására a kisebb települések népessége rohamosan csökkenhet (Novák et al., 2020). A vidéki térségek lakosságmegtartó képessége szempontjából kulcsfontossága van egyebek mellett annak is, hogy milyen munkalehetőségek és milyen sportolási, kulturális és szórakozási lehetőségek állnak a fiatalok rendelkezésére. Ez utóbbi elvárások vitathatatlanul alkalmasak a turisták szükségleteinek kielégítésére, hiszen a településekre csak rövidebb időre látogató vendégek is hasonló igényeket fogalmaznak meg szabadidejük eltöltése kapcsán, mint az állandó lakóhellyel az adott településen élő lakosság (Dajnoki et al., 2018; Kőmíves et al., 2018).

A nagy sportrendezvények számos hatása ismert, amelyek közül ki kell emelni a társadalmi és gazdasági hatásokat. Az ilyen események természetesen nemcsak városi, hanem vidéki környezetben is megrendezésre kerülhetnek, ebben az esetben ezek a pozitív hatások a jelen cikk keretében vizsgált térségekben is jelentkezhetnek. A társadalmi hatások közül ki kell emelni az egészségvédelmi következményeket és az interkulturális hatásokat, a gazdasági hatások sokrétűségét pedig jól példázzák a turizmus terén jelentkező fejlesztések, az ezekből keletkező bevételek is. A sportesemények vidéki megrendezését az egészséges környezet rendelkezésre állása is támogatja (Harangi-Rákos et al., 2019a; Harangi-Rákos et al., 2019b; Nagy et al., 2019).

Egy-egy ilyen sportesemény megrendezése akár a legkisebb települések számára is olyan kitörési lehetőséget jelent, amelynek eredményeként azok a legnépszerúbb turisztikai desztinációk körébe kerülhetnek. Magyarországon a legnépszerúbb turisztikai célpontok jellemzően a határokhoz közel, illetve bizonyos kiemelt turisztikai régiókban (például a Balaton közelében) találhatóak, ebbe a körbe új települések csak nehezen tudnak bekerülni. Ehhez jellemzően szükségük van valamilyen érdekességre (Oláh - Varga-Nagy, 2017).

\section{5. Összefoglalás}

Cikkem célja a vidék és a turizmus kapcsolatának szemléltetése volt szakirodalmi források elemzése útján. A feltárt szakirodalmak alapján megállapítottam, hogy a turisztikai fejlesztések eredményeként a vidéki térségek gazdasága is fejlődésnek indulhat.

A vidéki térségekhez számosan mindmáig egyfajta idilli ruralitás képét kötik. Ennek szerves részeként a potenciális turisták tekintélyes hányada olyan egészséges környezetként tekint a vidéki térségekre, amelyek többé-kevésbé képesek is megfelelni ezeknek az elvárásoknak. Ez a vidéki térségek számára is előnyös lehet, hiszen a rurális területek munkaerőpiaca jelentősen megváltozott, a mezőgazdasági foglalkoztatás ma már korántsem bír akkora jelentőséggel a lakosság munkáltatása szempontjából, mint a rendszerváltás idején tette.

Amennyiben tehát a vidék eléggé attraktív tud lenni a potenciális fogyasztók szemében, úgy a helyi gazdaságok fejlődésnek indulhatnak - nem kis részben a vendéglátás területén dolgozó helybéliek elkötelezettségének eredményeként. Mindez azért is fontos, mert a turisták egy része a tömegturizmus helyett valami egyedi, de nyugodt szórakozási lehetőségre vágyik. Amennyiben az ilyen utazók érdeklődését fel lehet kelteni, úgy hosszabb távra is fenntarthatóvá válik az idegenforgalom.

Köszönetnyilvánítás: A kutatás az EFOP3.6.3-VEKOP-16-2017-00007 "Tehetségből fiatal kutató" -A kutatói életpályát támogató tevékenységek a felsőoktatásban. címü projekt keretében valósulhatott meg. 


\section{Irodalomjegyzék}

[1] Bácsné Bába, É. - Ráthonyi, G. - Müller, A. - Ráthonyi-Odor, K. - Balogh, P. - Ádány, R. - Bács Z. (2020): Physical activity of the population of the most obese country in Europe, Hungary. Frontiers in Public Health 8, pp. 1-8.

[2] Dajnoki K. - Kun A. I. (2016): Frissdiplomások foglalkoztatásának jellemzői az agrárgazdaságban. Gazdálkodás, Vol. 6o, No. 4. pp. 289-304.

[3] Dajnoki K. - Szabados Gy. N. - Kulcsár G. - Kőmíves P. M. - Bácsné Bába É. (2018): „Visszatérni vidékre” - Hallgatói vidékképek kvalitatív megközelítésben. International Journal of Engineering and Management Sciences, Vol. 3, No. 5. pp. 204-216.

[4] Dancsokné Fóris E. - Szilvácsku Zs. - Valánszki I. (2019): Turizmusfejlesztési lehetőségek és korlátok a natúrparkokban. In: Kátay Á. - Michalkó G. - Rátz T. (szerk.): Turizmus 3.o. Kodolányi János Egyetem MTA CSFK Földrajztudományi Intézet - Magyar Földrajzi Társaság, Orosháza-Budapest. pp. 54-71.

[5] Egresi, I. (2016): Tourism and sustainability in Turkey: Negative impact of mass tourism development. In: Egresi, I. (szerk.): Alternative tourism in Turkey. GeoJournal Library, Vol. 121. Springer, Cham. pp. 35-53.

[6] Fenyves V. - Pető K. - Harangi-Rákos M. - Szenderák J. (2019): A Visegrádi országok mezőgazdasági vállalkozásainak gazdasági és pénzügyi helyzete. Gazdálkodás, Vol. 63, No. 6. pp. 459-473.

[7] Fenyves, V. - Pető, K. - Szenderák, J. - Harangi-Rákos, M. (2020): The capital structure of agricultural enterprises in the Visegrad countries. Agricultural Economics - Zemedelska Ekonomika, Vol. 66, No. 4. pp. 160-167.

[8] Fróna D. - Kőmíves P. M. (2019): A mezőgazdasági munkaerő sajátosságai. Gazdálkodás, Vol. 63, No. 5. pp. 361-380.

[9] Garau-Vadell, J. B. - Gutierrez-Taño, D. - Diaz-Armas, R. (2018): Economic crisis and residents' perception of the impacts of tourism in mass tourism destinations. Journal of Destination Marketing \& Management, Vol. 7. pp. 68-75.

[10] Gulyás P. (2019): A turizmus szerepe az alföldi járások fejlettségében. In: Farkas J. Zs. - Kovács, A. D. Perger É. - Lennert J. - Hoyk E. - Gémes T. (szerk.): Alföldi kaleidoszkóp. A magyar vidék a XXI. században. Tanulmányok a 70 éves Csatári Bálint köszöntésére. Magyar Tudományos Akadémia Közgazdaság- és Regionális Tudományi Kutatóközpont Regionális Kutatások Intézete, Kecskemét. pp. 106115 .

[11] Harangi-Rákos M. - Bács Z. - Szenderák J. (2019a): A 2012-es londoni nyári olimpia társadalmi hatásainak elemzése. In: Bácsné Bába É. - Müller A. (szerk.): „Mozgással az egészségért!” A fizikai aktivitás jelentősége a jövő munkavállalóinak egészségmegőrzésében. Nemzetközi Konferencia és Workshop. Válogatott tanulmánykötet. Debreceni Egyetem, Debrecen. pp. 161-175.

[12] Harangi-Rákos M. - Pöszmet T. - Nagy A. Sz. (2019b): A Formula 1 gazdasági hatásai. In: Balogh L. (szerk.): Sport és társadalom. Debreceni Egyetem Sporttudományi Koordinációs Intézet, Debrecen. pp. 83-92.

[13] Harris, C. (1998) Why research without theory is not research. A reply to Seymour, Crook and Rooke. Construction Management and Economics, Vol. 16, No. 1. pp. 113-116.

[14] Hegedűs, M (2013): Paradigmaváltozás szükségessége az egészségügyi rendszerben ACTA SCIENTIARUM SOCIALIUM $2013: 38$ pp. 199-207.

[15] Kiss Gy. (2018): Stratégia a helyi energiák fellelésére és megerősítésére: turisztikai attrakciók fejlesztése. Jelenkori Társadalmi és Gazdasági Folyamatok, Vol. 13, No. 1-2. pp. 169-175.

[16] Kothari, C. R. (2004): Research Methodology. Methods and Techniques. Second revised edition. New Age International Publishers, Új-Delhi.

[17] Kőmíves P. M. - Szabados Gy. N. - Kulcsár G. - Bácsné Bába É. - Fenyves V. - Dajnoki K. (2018): „Visszatérni vidékre” A sport megtartó ereje. International Journal of Engineering and Management Sciences, Vol. 3, No. 4. pp. 292-307.

[18] Kőmíves, P. M. - Pilishegyi, P. - Novák, N. - Nagy, A. Sz. - Körösparti, P. (2019): The role of the higher education in the development of agriculture. International Journal of Information and Education Techology, Vol. 9, No. 9. pp. 607-612.

[19] Lee, J. W. - Syah, A. M. (2018): Economic and environmental impacts of mass tourism on regional tourism destinations in Indonesia. Journal of Asian Finance, Economics and Business, Vol. 5, No. 3. pp. 31-41.

[20]Mezei, K. - Troján, Sz. - Lipcseiné Takács, N. (2018): The grass is always greener on the other side, or else. Austria through the eyes of European rural developers. DETUROPE - The Central European Journal of Regional Development and Tourism, Vol. 10, No. 3. pp. 199-213. 
[21] Müller A. - Pfau C. - Gabnai Z. - Bácsné Bába É. - Borbély A. - Pető K. (2018): A gyógy-, wellness- és sportszolgáltatások fejlesztési lehetőségei a gyógyturizmusban egy hazai kutatás tükrében. International Journal of Engineering and Management Sciences, Vol. 3, No. 4. pp. 101-114.

[22]Nagy A. Sz. - Szabados Gy. N. - Szenderák J. - Harangi-Rákos M. (2019): A Formula 1 társadalmi hatásainak elemzése. In: Bácsné Bába É. - Müller A. (szerk.): „Mozgással az egészségért!” A fizikai aktivitás jelentősége a jövő munkavállalóinak egészségmegőrzésében. Nemzetközi Konferencia és Workshop. Válogatott tanulmánykötet. Debreceni Egyetem, Debrecen. pp. 149-160.

[23]Nemes G. (2018): A társadalmi innováció és integrált vidékfejlesztés - két jó gyakorlat. Északmagyarországi Stratégiai Füzetek, Vol. 15, No. 3. pp. 69-78.

[24] Novák, N. - Kőmíves, P. M. - Harangi-Rákos, M. - Pető, K. (2020): The role of rural areas in the preservation of health. International Review of Applied Sciences and Engineering, Vol. 11, No. 2. pp. 1-25.

[25] Oláh I. - Áldorfai Gy. - Béres-Virág Á. (2017): A települések egyenlőtlenségei turisztikai szempontból. Studia Mundi - Economica, Vol. 4, No. 4. pp. 38-48.

[26] Oláh I. - Varga-Nagy A. (2017): A turizmus mint lehetőség a magyarországi törpefalvak példáján. Pro Scientia Ruralis, Vol. 2, No. 1. pp. 102-110.

[27] Popp J. - Szenderák J. - Fróna D. - Felföldi J. - Oláh J. - Harangi-Rákos M. (2018): A magyar mezőgazdaság teljesítménye 2004-2017 között. Jelenkori Társadalmi és Gazdasági Folyamatok, Vol. 13, No. 3-4. pp. 9-20.

[28]Szőllősi L. - Szűcs I. - Molnár Sz. - Ladányi K. (2014): A helyi kézműves termék-elóállítás és -forgalmazás során felmerülő együttműködés lehetőségei egyes kiemelt turisztikai vonzerővel rendelkező erdélyi településeken. Journal of Central European Green Innovation, Vol. 2, No. 3. pp. 111-134.

[29]Vargáné Csobán K. - Serra Gy. (2016): A sportturizmus lehetőségei a vidékfejlesztésben az Észak-Alföldi régió példáján. Köztes-Európa, Vol. 8, No. 1-2. pp. 145-156. 